\title{
AWARENESS AMONG HEALTH CARE PROFESSIONALS REGARDING NOSOCOMIAL PATHOGENS AND ROLE OF FOMITES IN THEIR TRANSMISSION.
}

1. B.Sc, MLT Student

Punjab Institute of Cardiology

2. MBBS, M.Phil (Microbiology)

Associate Professor Pathology

Rai Medical College, Sargodha.

3. MBBS, M.Phil (Microbiology) Consultant Pathologist Punjab Institute of Cardiology

4. MBBS, M.Phil (Histopathology) Associate Professor Pathology Rai Medical College, Sargodha.

5. MBBS, M.Phil (Histopathology) Consultant Histopathology Punjab Institute of Cardiology

6. MBBS, M.Phil (Hematology) Professor Pathology

Punjab Institute of Cardiology

Correspondence Address:

Dr. Nadia Aslam

Department of Pathology

Rai Medical College, Sargodha.

drnadia76@yahoo.com

Article received on:

13/09/2019

Accepted for publication:

$22 / 11 / 2019$
Khadija Mumtaz ${ }^{1}$, Nadia Aslam², Naima Mehdi ${ }^{3}$, Nazma Kiran4, Sadaf Farzand ${ }^{5}$, Mahfooz ur Rahman 6

ABSTRACT... Objectives: This study was performed to access the knowledge of health care professionals regarding health care associated infections, nosocomial pathogens, fomites and their role in transmission of nosocomial pathogens. Study Design: Descriptive, questionnaire based, cross-sectional study. Setting: Tertiary care hospital of Lahore, Punjab. Period: From October 2017 to January 2018. Material \& Methods: Questionnaires were carefully formulated to access basic knowledge of physicians, surgeons and nurses. Responses given were analyzed and recorded as frequency and percentage. Results: Regarding health care associated infections, respiratory tract infections were identified by $72 \%$ surgeons, $65 \%$ physicians and $59 \%$ nurses. Surgical wound infections were identified by $76 \%$ of surgeons and $81 \%$ nurses. $45.7 \%$ physician identified bacteraemia as nosocomial infection. Rate of identification for rest of nosocomial infections was sub optimum $(<50 \%)$ by health care workers. Regarding identification of nosocomial pathogens, Methicillin Resistant Staphylococcus aureus was marked by $65 \%$ of physicians, $83.8 \%$ of nurses, $76 \%$ of surgeons. Pseudomonas nosocomial pathogen was identified by $40 \%, 46 \%$ and $64 \%$ of physicians, nurses and surgeons respectively. The rate of identification for rest of the nosocomial organisms was again sub optimum $(<40 \%)$ by health care workers. Regarding fomites, mattresses and pillows, thermometer, stethoscopes were identified by $75.7 \%, 59.2$ and $50 \%$ of Health care professionals respectively. Conclusion: This survey identified positive attitude among Health care workers towards infection control but low level of knowledge regarding health care associated infections and nosocomial pathogens. Therefore, to prevent nosocomial infections, there is strong need to develop strategies for improving knowledge of Health care professionals.

Key words: $\quad$ Nosocomial Pathogens, Fomites, Health Care Associated Infections, Health Care Workers.

Article Citation: Mumtaz K, Aslam N, Mehdi N, Kiran N, Farzand S, Mahfooz ur Rehman. Awareness among health care professionals regarding nosocomial pathogens and role of fomites in their transmission. Professional Med $\mathrm{J}$ 2020; 27(5):1032-1037. DOI: 10.29309/TPMJ/2020.27.05.4149

\section{INTRODUCTION}

Health care-associated infection (HCAl) or "nosocomial" infection, is an infection acquired by a patient during stay in a hospital or health care facility and infection was not present or incubating at the time of hospital admission. A large number of patients around the world are affected by HCAls but loads of HCAls is much higher in developing countries as compared to developed ones. HCAls not only leads to prolonged hospital stay and spread of drug resistant strains leading to excess costs for health systems as well as for patients but also excess morbidity and unnecessary deaths. ${ }^{1}$

Fomites are inanimate objects or surfaces that can act as vehicles in transmission of pathogens. Fomites can get contaminated by direct contact with body secretions or fluids, soiled hands or aerosolized pathogen. Transfer of pathogens may occur between inanimate and animate objects, or between different inanimate objects. ${ }^{2}$

Nosocomial pathogens like Vancomycin Resistant Enterococcus (VRE), Methicillin resistant Staphylococcus Aureus (MRSA), Streptococcus pyogenes, Acinetobacter spp., Escherichia coli, Klebsiella spp., Pseudomonas aeruginosa, Serratia marcescens, or Shigella spp can survive on dry surfaces for months. ${ }^{3}$ 
Inanimate surfaces and equipment (e.g., bedrails, stethoscopes, medical charts, ultrasound machine) may get contaminated by multi drug resistant (MDR) isolates and play role in crosstransmission of microorganisms. ${ }^{4}$ Hands of healthcare workers (HCWs) may get contaminated after contact with emergency carts and trolleys or after using phones, medical charts, stethoscopes, monitors and ventilators thus playing a role in nosocomial spread of pathogens..$^{5,6,7}$

This questionnaire based survey was performed to access knowledge of physicians, surgeons and nurses regarding infections acquired in health care setting, nosocomial pathogens and role of fomites in the transmission of nosocomial pathogens. Interrupting chain of transmission of nosocomial pathogens is of utmost importance in preventing these HCAls. To break chain of transmission, HCWs must have adequate knowledge regarding the pathogens surviving in hospital environments, their mode of transmission and infections caused by such pathogens.

\section{MATERIAL \& METHODS}

This study was conducted in Punjab Institute of Cardiology (PIC), a tertiary care hospital in Punjab, with 292 bed and providing comprehensive cardiac care services to their patients. Data was collected from October 2017 to January 2018. Questionnaires were completed by health care workers including physicians, surgeons and nurses working in various departments of hospital after taking consent. Questions accessing HCWs knowledge of various HCAls, pathogens responsible for causing infections among hospitalized patients and role of various inanimate objects in nosocomial spread of pathogens were included in questionnaire. Answers given by various respondents were analyzed and recorded as frequency and percentage.

\section{RESULTS}

Questionnaires were analyzed to access knowledge of the health care workers. Of total 140 respondents, 131 (93.6\%) considered themselves as aware of health care associated infections in this hospital while 9 (6.4\%) were unaware of HCAls.

\begin{tabular}{|c|c|c|}
\hline $\begin{array}{l}\text { Are you aware of } \\
\text { HCAls in Hospitals? }\end{array}$ & Frequency & Percent \\
\hline Yes & 131 & 93.6 \\
\hline No & 9 & 6.4 \\
\hline Total & 140 & 100.0 \\
\hline
\end{tabular}

Regarding HCAls prevalent in PIC hospital, respiratory tract infection (RTI) was identified by $72 \%$ surgeons, $65 \%$ physicians and $59 \%$ nurses. Surgical wound infections were identified by $76 \%$ of surgeons and $81 \%$ nurses. $45.7 \%$ physician identified bloodstream infection. Rate of identification of all the other infections was $<50 \%$ for all the three professionals.

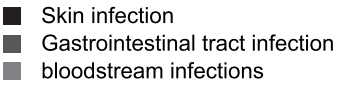

Respiratory tract infections - Surgical wound infections Urinary tract infection

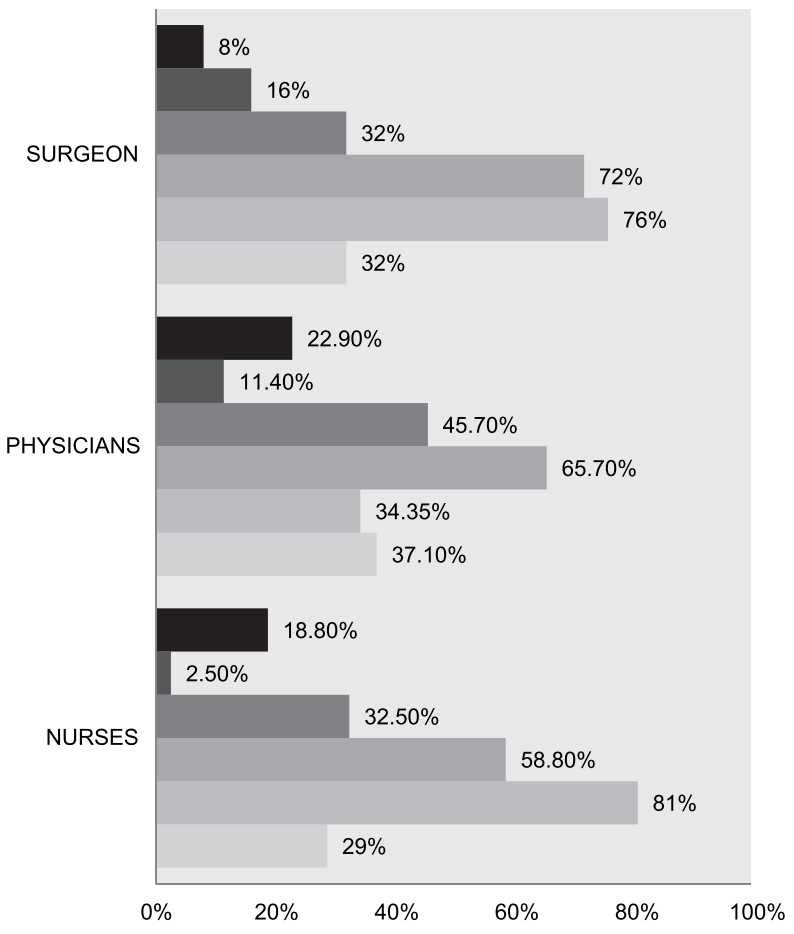

Figure-1. Showing response of health care workers regarding nosocomial infections.

Knowledge of health care workers regarding nosocomial pathogens was accessed by asking multiple choice questions, most of health care workers identified MRSA and Pseudomonas as nosocomial pathogens. MRSA was identified by $76 \%$, Pseudomonas by 64 , Klebsiella by $44 \%$, E. coli by $40 \%$ of surgeons as nosocomial 
pathogens while knowledge regarding rest of pathogens was deficient. Responses of Surgeons are shown in Figure-2.

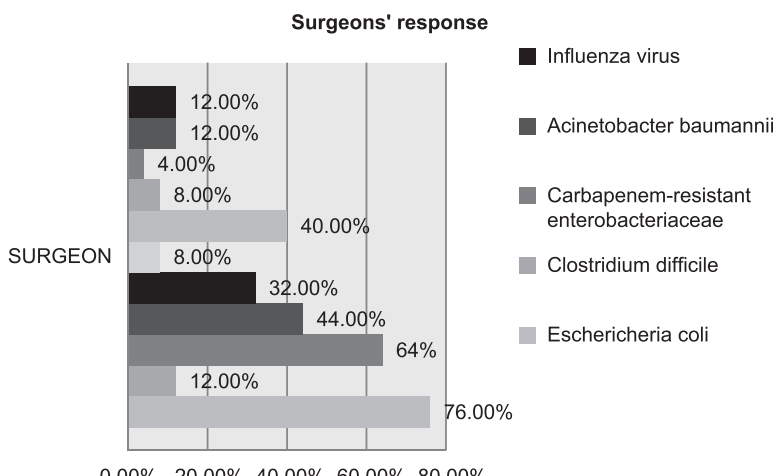

Figure-2. Showing Surgeons' response regarding nosocomial pathogens.

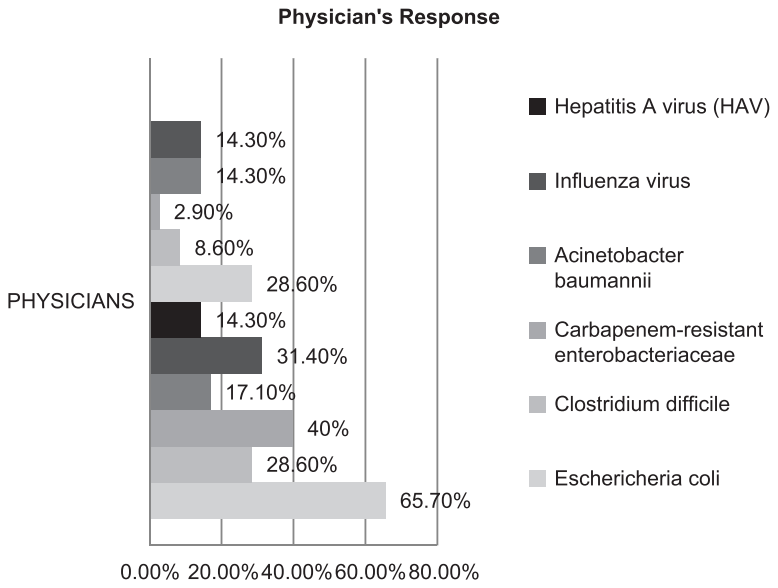

Figure-3. Showing physicians' response regarding nosocomial pathogens.

Responses of physicians' regarding nosocomial pathogens were recorded and are shown in Figure-3. Only $65.7 \%$ of physicians identified
MRSA, 40\% Pseudomonas, 28.6\% VRE and E.coli as nosocomial pathogens.

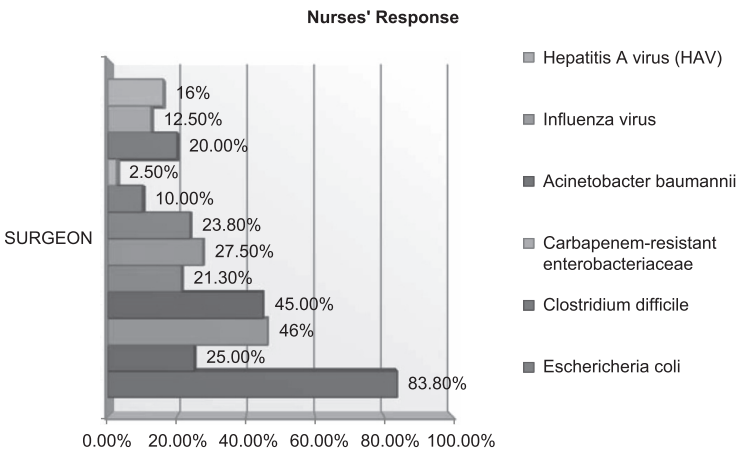

Figure-4. Showing nurses' response regarding nosocomial pathogens.

Responses of nurses regarding nosocomial pathogens were recorded and are shown in Figure-4. MRSA was identified as nosocomial pathogen by $83.8 \%$ nurses, Pseudomonas by $46 \%$, Klebsiella by $45 \%$, E. coli by $23.8 \%$ and VRE by $25 \%$.

Regarding Fomites, blood pressure cuff (sphygmomanometer) was identified by $46 \%$ nurses, $6 \%$ physicians and $5 \%$ of surgeons. White coat was identified by $31.3 \%$ nurses, 71.4 $\%$ physicians and $40 \%$ of surgeons. Stethoscope was identified by $62.5 \%$ nurses, $42.9 \%$ physicians and $20 \%$ of surgeons, mattresses and pillows were identified by $82.5 \%$ nurses, $60 \%$ physicians and $76 \%$ of surgeons. Responses of Surgeons, physicians and nurses regarding various inanimate objects playing role in transmission of nosocomial pathogens morbidity are shown in Table-I.

\begin{tabular}{|l|c|c|c|c|}
\hline $\begin{array}{c}\text { Which of the followings } \\
\text { you consider as fomites? }\end{array}$ & $\begin{array}{c}\text { Physicians } \\
(\mathbf{3 5 )}\end{array}$ & $\begin{array}{c}\text { Nurses } \\
\mathbf{( 8 0 )}\end{array}$ & $\begin{array}{c}\text { Surgeons } \\
(\mathbf{2 5 )}\end{array}$ & $\begin{array}{c}\text { Total } \\
(\mathbf{1 4 0 )}\end{array}$ \\
\hline White coat & $25(\mathbf{7 1 . 4 \% )}$ & $25(31.3 \%)$ & $10(40 \%)$ & $60 / 140=42.9 \%$ \\
\hline Nurse uniform & $14(40 \%)$ & $32(40 \%)$ & $7(28 \%)$ & $53 / 140=37.9 \%$ \\
\hline Stethoscope & $15(42.9 \%)$ & $50(62.5 \%)$ & $5(20 \%)$ & $70 / 140=50 \%$ \\
\hline Thermometer & $14(40 \%)$ & $65(81.3 \%)$ & $4(16 \%)$ & $83 / 140=59.2 \%$ \\
\hline Wrist watch (for patient care) & $4(11.4 \%)$ & $23(28.8 \%)$ & $1(4 \%)$ & $28 / 140=20 \%$ \\
\hline Blood pressure cuff & $6(17.15 \%)$ & $46(57.5 \%)$ & $5(20 \%)$ & $57 / 140=40.7 \%$ \\
\hline Mattresses and pillows & $21(60 \%)$ & $66(82.5 \%)$ & $19(76 \%)$ & $106 / 140=75.7 \%$ \\
\hline Bedside curtains & $10(28.6 \%)$ & $30(37.55)$ & $7(28 \%)$ & $47 / 140=33.6 \%$ \\
\hline Chair/stools/cabinets & $4(11.4 \%)$ & $21(26.3 \%)$ & $6(24 \%)$ & $31 / 140=22.1 \%$ \\
\hline Air conditioners & $10(28.6 \%)$ & $11(13.8 \%)$ & $8(32 \%)$ & $29 / 140=20.7 \%$ \\
\hline
\end{tabular}

Table-I. Showing response of physicians, nurses and surgeons regarding fomites. 


\section{DISCUSSION}

Regarding HCAl, surgical wound infection and respiratory tract infection were identified by majority of respondents while most of the respondents were unaware of bacteremia and UTI as HCAls. Blood stream infection especially catheter associated blood stream infections are a major cause of concern in hospitalized patients. Central venous catheter use can lead to complications like Central line-associated bloodstream infection (CLABSI). ${ }^{8}$ Healthcare workers should get training and quality control programmes should be implemented to minimize catheter related infections. ${ }^{9}$

A large proportion of HCWs failed to identify gastrointestinal tract infection as HCAls especially Clostridium difficile infections related knowledge was deficient and need to be improved as that is Clostridium difficile is a major cause of HCAls and leads to change and limit treatment options for the patients. $C$ difficile is a major cause of diarrhea in patients undergoing antibiotic therapy. Patients can suffer from complications like colonic ileus, toxic megacolon and multiorgan failure. ${ }^{10}$

Regarding nosocomial pathogens, most of the respondents accurately identified MRSA and Pseudomonas as nosocomial pathogens. Knowledge regarding rest of the infectious agents commonly implicated in HCAls was poor. VRE is a frequent cause of nosocomial infections and are associated with increased hospital costs and higher mortality. ${ }^{11}$

Knowledge regarding importance of Carbapenemase producing Enterobactereicea especially E. coli and Klebsiella in HCAls was poor. E. coli is a major cause of UTI, septicemia, pneumonia, neonatal meningitis, peritonitis and gastroenteritis. ${ }^{12} \mathrm{~K}$. pneumonia is notorious for neonatal septicaemia, pneumonia, wound infections and septicemia. ${ }^{12}$

Acinetobacter as a nosocomial pathogen was not identified by majority of HCWs. The genus Acinetobacter is a member of skin flora, often drug resistant and a major cause of nosocomial infections especially urinary and respiratory tract infections and peritonitis in patients with indwelling devices. ${ }^{13}$ Acinetobacter infections are associated with high mortality rates. ${ }^{13,14}$

A large number of respondents (approx. 32\% of surgeon and $21 \%$ of physicians) marked Streptococcus pneumoniae as a cause of HCAls. However, Streptococcus pneumoniaeisa common cause of community acquired pneumonia instead of hospital acquired pneumonia. ${ }^{15}$ Therefore, Strep pneumoniae which is cause of community associated infections was wrongly identified as a cause of health care associated infection by HCWs. This shows a large gap for knowledge.

Regarding fomites as a vehicle of transmission of pathogens, knowledge regarding white coats and nurse uniforms as fomites was deficient. White coats can harbor potential contaminants and play a role in the nosocomial transmission of pathogenic microorganisms. Infectious microorganisms shed by patients can contaminate and survive on fabrics used to make white coats. ${ }^{16}$

Various studies have shown role ofWrist watches ${ }^{17}$, Blood pressure cuffs $^{18}$, bedside curtains $^{19}$, chair/stools/cabinets ${ }^{19}$, air conditioners $^{20}$ in transmission of pathogens.

\section{CONCLUSION}

This survey found that the knowledge of HCWs regarding HCAls, nosocomial infections and role of various fomites in spread of nosocomial pathogens was not upto the mark. Appropriate knowledge and approach for preventing HCAls by avoiding transmission of nosocomial pathogens by fomites is mandatory. Therefore, in hospitals, workshops and CME sessions should be organized on regular basis to improve understanding of HCAls, nosocomial pathogens and modes of nosocomial spread of infection. Improving the knowledge will change the attitude towards infection control practices and lead to reduction in HCAls and decrease in patient morbidity and mortality.

Copyright $(22$ Nov, 2019. 


\section{REFERENCES}

1. WHO. The burden of health care-associated infection worldwide(2016) [Online] Available from: http://www. who.int/gpsc/country_work/burden_hcai/en/

2. Boone SA, Gerba CP. Significance of fomites in the spread of respiratory and enteric viral disease. Appl. Environ. Microbiol.. 2007 Mar 15;73(6):1687-96.

3. Kramer A, Schwebke I, Kampf G. How long do nosocomial pathogens persist on inanimate surfaces? A systematic review. BMC infectious diseases. 2006 Dec;6(1):130.

4. Russotto V, Cortegiani A, Raineri SM, Giarratano A. Bacterial contamination of inanimate surfaces and equipment in the intensive care unit. Journal of intensive care. 2015 Dec 1;3(1):54. doi: 10.1186/ s40560-015-0120-5

5. Hayden MK, Blom DW, Lyle EA, Moore CG, Weinstein RA. Risk of hand or glove contamination after contact with patients colonized with vancomycinresistant enterococcus or the colonized patients' environment. Infect Control. 2008; 29(02):149-54.

6. Huslage K, Rutala WA, Sickbert-Bennett E, Weber DJ. A quantitative approach to defining "high-touch" surfaces in hospitals. Infect Control. 2010; $31(08): 850$ 3.

7. Longtin $\mathrm{Y}$, Sax H, Allegranzi B, Schneider F, Pittet D. Hand hygiene. N Engl J Med. 2011; 364(13):e24.

8. Guenezan J, Drugeon B, Marjanovic N, Mimoz O. Treatment of central line-associated bloodstream infections. Crit Care. 2018; 22(1):303. doi: 10.1186/ s13054-018-2249-9.

9. Timsit JF, L'Heriteau F, Lepape A, Francais A, Ruckly S, Venier AG, et al: A multicenter analysis of catheterrelated infection based on a hierarchical model. Intensive Care Med. 2012, 38 (10): 1662-72. Epub 2012/07/17. https://link.springer.com/article/10.1007/ s00134-012-2645-6.

10. Martinez FJ, Leffler DA, Kelly CP. Clostridium difficile outbreaks: Prevention and treatment strategies. Risk Manag Healthc Policy 2012; 5: 55-64. doi: 10.2147/ RMHP.S13053.
11. Puchter L, Chaberny IF, Schwab F, Vonberg R-P, Bange $F-C$, Ebadi E. Economic burden of nosocomial infections caused by vancomycin-resistant enterococci. Antimicrob Resist Infect Control. 2018; 7:1. https://aricjournal.biomedcentral.com/track/ pdf/10.1186/s13756-017-0291-z

12. Khan HA, Ahmad A, Mehboob R. Nosocomial infections and their control strategies. Asian Pacific Journal of Tropical Biomedicine.2015; 5(7): 509-14. https://doi.org/10.1016/j.apjtb.2015.05.001

13. Almasaudi SB. Acinetobacter spp. as nosocomial pathogens: Epidemiology and resistance features. Saudi J Biol Sci. 2018;25(3):586-96 https:// doi.org/10.1016/j.sjbs.2016.02.009

14. Jung J, Park W. Acinetobacter species as model microorganisms in environmental microbiology: Current state and perspectives. Appl. Microbiol. Biot. 2015, 99 (6), 2533-2548.

15. File TM. Streptococcus pneumoniae and communityacquired pneumonia: A cause for concern. Am J Med 2004; 117:39S-50S.

16. Banu $A$, Anand $M$, Nagi $N$, White coats as a vehicle for bacterial dissemination. J ClinDiagn Res. 2012; 6 (8):1381-4. doi: 10.7860/JCDR/2012/4286.2364.

17. Velvizhi G, Anupriya G, Sucilathangam G, Ashihabegum MA., Jeyamurugan T, Palaniappan N. Wristwatches as the potential sources of hospital-acquired infections. Journal of Clinical and Diagnostic Research. 2012, Vol6(5): 807-810.

18. Baruah J, Kumar S, Gratix A, Dibb W, Madeo M. Blood pressure cuffs as a potential fomite for transmission of pathogenic micro-organisms: A prospective study in a university teaching hospital. $J$ Infect Prev 2008; 9: 19-21. https://doi.org/10.1177\%2F1469044608091150.

19. Boyce JM, Potter-Bynoe G, Chenevert C, King T. Environmental contamination due to methicillinresistant Staphylococcus aureus: Possible infection control implications. Infect Control Hosp Epidemiol.1997;18:622-7

20. Fernstrom A, Goldblatt M. Aerobiology and Its role in the transmission of infectious diseases. J Pathog. 
2013: 493960. doi: 10.1155/2013/493960.

\begin{tabular}{|c|l|l|l|}
\hline \multicolumn{2}{|c|}{ AUTHORSHIP AND CONTRIBUTION DECLARATION } \\
\hline Sr. \# & \multicolumn{1}{|c|}{ Author(s) Full Name } & Contribution to the paper & Author(s) Signature \\
\hline 1 & Khadija Mumtaz & Author & Khadija \\
2 & Nadia Aslam & Co-Author & \\
3 & Naima Mehdi & Co-Author & \\
4 & Nazma Kiran & Co-Author \\
\hline 5 & Sadaf Farzand & Co-Author & \\
\hline 6 & Mahfooz ur Rahman & Co-Author & Maufou \\
\hline
\end{tabular}

